\title{
Transjugular intrahepatic portasystemic stent shunting for control of acute and recurrent upper gastrointestinal haemorrhage related to portal hypertension
}

\author{
K J Simpson, N Chalmers, D N Redhead, N D C Finlayson, I A D Bouchier, P C Hayes
}

\begin{abstract}
The insertion of a transjugular intrahepatic portasystemic stent shunt (TIPSS) was evaluated in 22 patients with recurrent upper gastrointestinal haemorrhage related to portal hypertension (bleeding from oesophageal varices 10 , gastric varices six, portal hypertensive gastropathy six). TIPSS was successfully performed electively in $\mathbf{1 5}$ patients and as an emergency in three patients. Twelve patients have had no further admissions with bleeding after TIPSS. Single episodes of bleeding were noted in six patients after TIPSS associated with shunt thrombosis (two), intimal hyperplasia within the shunt (two), and shunt migration (one). Another patient presented with reaccumulated ascites suggesting poor shunt function but died from massive variceal haemorrhage before further assessment could be performed. There was one death related to the procedure. Two patients developed encephalopathy after TIPSS, in one patient this was controlled by the insertion of a smaller diameter stent within the existing TIPSS. Several complications arose in earlier patients that have not recurred after modification of the initial technique. TIPSS can be life saving and is effective in controlling variceal haemorrhage and rebleeding from oesophageal or gastric varices and portal hypertensive gastropathy. Larger and longer term studies are required, however, to define the role of TIPSS in the overall management of such patients.

(Gut 1993; 34: 968-973)
\end{abstract}

Many treatments have evolved over the last 30 years for controlling upper gastrointestinal haemorrhage in patients with cirrhosis and portal hypertension. Bleeding varices may be controlled initially by pharmacological measures, ${ }^{12}$ balloon tamponade,$^{3}$ endoscopic sclerotherapy, ${ }^{4}$ oesophageal transection, ${ }^{5}$ or emergency portasystemic shunt surgery. ${ }^{6}$ The problem of rebleeding remains, however, except in patients treated with shunt surgery. Long term oral propranolol treatment or repeated endoscopic injection sclerotherapy are similarly effective in reducing rebleeding that still occurs in up to $60 \%$ of patients and neither have been shown consistently to improve survival. ${ }^{7-13}$ Nonemergency portasystemic shunt surgery is effective in preventing rebleeding but is still associated with high perioperative mortality in Child's grade $\mathrm{C}$ patients and postoperative encephalopathy occurs in up to $40 \%$ of patients. ${ }^{14-17}$

A percutaneous transjugular technique for placement of an intrahepatic portasystemic shunt was first described in animals in $1969 .{ }^{18}$ Subsequent modifications in the technique resulted in long term maintenance of shunt patency and infrequent migration of the internal stents. ${ }^{19-22}$ Early experience with the technique in patients was disappointing. Balloon catheters were used to dilate the intrahepatic parenchymal fistulous tracts but metallic stents were not available and long term patency was not maintained. ${ }^{2324} \mathrm{~A}$ transjugular intrahepatic portasystemic stent shunt (TIPSS), inserting metallic expandable stents, was first described in 1989 in a patient with Child's $\mathrm{C}$ alcoholic cirrhosis and recurrent bleeding from oesophageal varices. ${ }^{25}$ After successful TIPSS, the portal pressure gradient fell from 38 to $18 \mathrm{~mm} \mathrm{Hg}$ and no further haemorrhage occurred. Unfortunately, the patient died from septicaemia 11 days after TIPSS but postmortem examination of the stent showed internal epithelialisation and continued patency. Subsequent reports have shown TIPSS to be a safe and effective method for treating recurrent variceal haemorrhage and cases of encephalopathy after TIPSS are rare. ${ }^{26-32}$

We report here our early experience of TIPSS in 22 patients with recurrent upper gastrointestinal haemorrhage related to portal hypertension.

\section{Patients and methods}

Table I shows details of patients. The indications for TIPSS were bleeding from gastric varices (six patients) or recurrent bleeding from oesophageal varices that had not responded to repeated injection sclerotherapy (10 patients, number of bleeds two to more than 10 before TIPSS). TIPSS was performed in six patients with bleeding from portal hypertensive gastropathy that required recurrent transfusions, in whom propranolol was contraindicated or ineffective. In four patients TIPSS was attempted as an emergency procedure; the remaining procedures were performed electively.

The basic TIPSS technique used incorporated modifications similar to those described by Zemel $e t a l^{28}$ and Rössle et $a l,{ }^{26}$ based on the original method of Richter ${ }^{25}$ and are described in detail in our previous report..$^{33}$

Intravenous midazolam and pethidine were used to provide sedation and analgesia through- 
TABLE I Details of patients considered for TIPSS

\begin{tabular}{|c|c|c|c|c|c|c|}
\hline $\begin{array}{l}\text { Patient } \\
\text { No }\end{array}$ & Age & Sex & $\begin{array}{l}\text { Aetiology of } \\
\text { cirrhosis }\end{array}$ & $\begin{array}{l}\text { Child-Pugh } \\
\text { score }\end{array}$ & Other illnesses & Bleeding source \\
\hline $\begin{array}{l}1 \\
2 \\
3\end{array}$ & $\begin{array}{l}71 \\
54 \\
71\end{array}$ & $\begin{array}{l}\mathbf{M} \\
\mathbf{M} \\
\mathbf{M}\end{array}$ & $\begin{array}{l}\text { Alcohol } \\
\text { Alcohol } \\
\text { Chronic HBV and } \\
\text { HDV infection }\end{array}$ & $\begin{array}{l}\mathbf{B}_{8} \\
\mathbf{A}_{5} \\
\mathbf{A}_{6}\end{array}$ & $\begin{array}{l}\text { Gout } \\
\text { Gout, hypertension } \\
\text { Peripheral vascular disease, } \\
\text { hypertension, non-insulin } \\
\text { dependent diabetes, previous } \\
\text { cerebrovascular accident }\end{array}$ & $\begin{array}{l}\text { Gastric varices } \\
\text { Oesophageal varices } \\
\text { Gastric varices }\end{array}$ \\
\hline 4 & 60 & $\mathbf{M}$ & Alcohol & $\mathbf{B}_{8}$ & $\begin{array}{l}\text { Previous myocardial infarction, } \\
\text { angina }\end{array}$ & Portal hypertensive gastropathy \\
\hline $\begin{array}{l}5 \\
6\end{array}$ & $\begin{array}{l}51 \\
73\end{array}$ & $\mathbf{M}$ & $\begin{array}{l}\text { Alcohol } \\
\text { PBC }\end{array}$ & $\begin{array}{l}\mathbf{B}_{7} \\
\mathbf{A}_{5}\end{array}$ & $\begin{array}{l}\text { Asthma } \\
\text { None }\end{array}$ & $\begin{array}{l}\text { Gastric varices } \\
\text { Oesophageal varices }\end{array}$ \\
\hline 7 & 72 & $\mathbf{M}$ & Cryptogenic & $\mathbf{B}_{\mathbf{8}}$ & $\begin{array}{l}\text { Previous myocardial infarction, } \\
\text { angina, hypertension, non-insulin } \\
\text { dependent diabetes, asthma }\end{array}$ & Oesophageal varices \\
\hline 8 & 66 & $\mathrm{~F}$ & PBC & $\mathrm{C}_{10}$ & $\begin{array}{l}\text { Previous myocardial infarction, } \\
\text { angina, asthma }\end{array}$ & $\begin{array}{l}\text { Gastric varices, portal hypertensive } \\
\text { gastropathy }\end{array}$ \\
\hline 9 & 54 & $\mathbf{M}$ & Alcohol & $\mathrm{C}_{14}$ & Non-insulin dependent diabetes & Portal hypertensive gastropathy \\
\hline 10 & 56 & $\mathbf{F}$ & Alcohol & $\mathrm{C}_{14}$ & Bleeding gastric ulcer, fractured hip & Gastric varices \\
\hline 11 & 63 & $\mathbf{M}$ & Alcohol & $\mathrm{A}_{5}$ & None & Oesophageal varices \\
\hline 12 & 20 & $\mathbf{M}$ & Cryptogenic & $\mathrm{A}_{5}$ & None & Oesophageal varices \\
\hline 13 & 50 & $\mathbf{F}$ & PBC & $\mathrm{B}_{7}$ & None & Oesophageal varices \\
\hline 14 & 52 & $\mathrm{~F}$ & PBC & $\mathrm{A}_{6}$ & None & Oesophageal varices \\
\hline 15 & 41 & $\mathbf{M}$ & $\begin{array}{c}\text { Chronic HBV and } \\
\text { HDV infection }\end{array}$ & $\mathrm{C}_{10}$ & AIDS & Oesophageal varices \\
\hline 16 & 54 & $\mathbf{F}$ & PBC & $A_{5}$ & None & Oesophageal varices \\
\hline 17 & 57 & $\mathbf{M}$ & Alcohol & $\mathrm{C}_{11}$ & None & Oesophageal varices \\
\hline 18 & 63 & $\mathbf{M}$ & Alcohol & $\mathbf{B}_{7}$ & None & Gastric varices \\
\hline 19 & 62 & $\mathbf{F}$ & PBC & $\mathrm{A}_{5}$ & None & Portal hypertensive gastropathy \\
\hline 20 & 52 & $\mathbf{F}$ & Alcohol & $\mathbf{B}_{8}$ & None & Portal hypertensive gastropathy \\
\hline 21 & 44 & $\mathbf{F}$ & Alcohol & $\mathrm{C}_{11}^{\circ}$ & None & Portal hypertensive gastropathy \\
\hline 22 & 49 & $\mathbf{F}$ & Alcohol & $A_{5}$ & None & Gastric varices \\
\hline
\end{tabular}

$\mathrm{PBC}=$ Primary biliary cirrhosis

out the procedure. During the procedure the patients received oxygen ( 2 litres/minute), via nasal cannulae and heart rate and oxygen saturation were monitored continuously.

After cleaning and draping the right side of the neck in a sterile fashion, local anaesthetic (1\% lignocaine) was instilled and a 10 French $35 \mathrm{~cm}$ long sheath (William Cook, Europe) was inserted into the right internal jugular vein. The right or middle hepatic vein was then catheterised under fluoroscopic screening and the tip of the sheath advanced into the hepatic vein. A 16 gauge $56 \mathrm{~cm}$ reversed bevel curved transjugular liver biopsy needle (William Cook, Europe) was introduced through the sheath into the hepatic vein, directed anteriorly, and advanced through the liver parenchyma to puncture a large portal

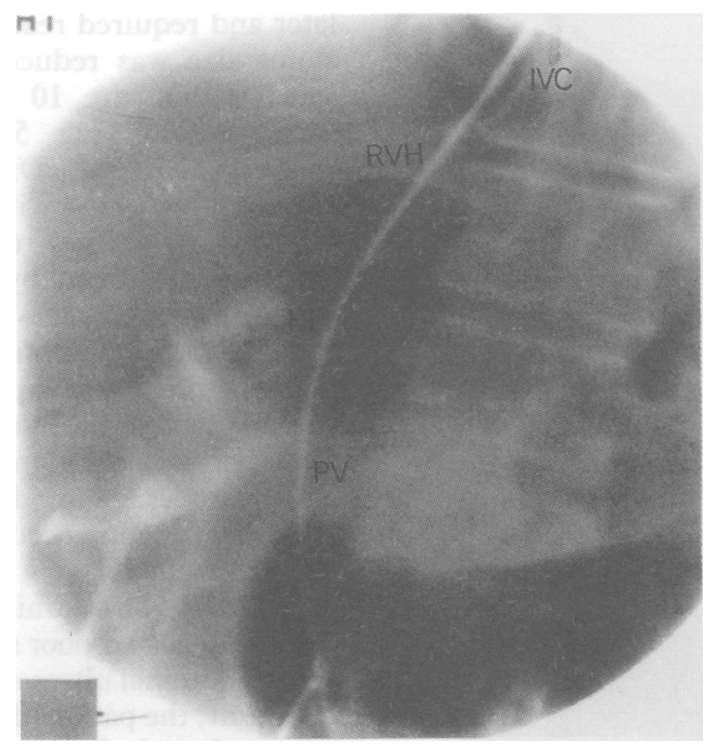

Figure 1: Guide wire introduced via the right internal jugular vein through the inferior vena cava (IVC), right hepatic vein $(R V H)$, and hepatic parenchyma $(H P)$ into the portal vein $(P V)$. vein branch. Successful cannulation of the portal vein was preceded by a characteristic 'give'. A stiff guidewire was then passed through the transjugular biopsy needle into the superior mesenteric vein (Fig 1), the needle removed, and a catheter introduced over the wire into the portal vein. Correct placement of the catheter was confirmed by portography (Fig 2) and direct portal venous pressure measurement was recorded. In the first five patients and patient 12 a percutaneous transhepatic catheter was placed into the portal vein to act as a target for the transjugular needle. In the other patients a portagram alone, visualised by mesenteric angiography on the previous day, was used for guidance.

The transhepatic parenchymal tract was subsequently dilated wth an $8 \mathrm{~mm}$ angioplasty balloon; on initial inflation a characteristic sharp

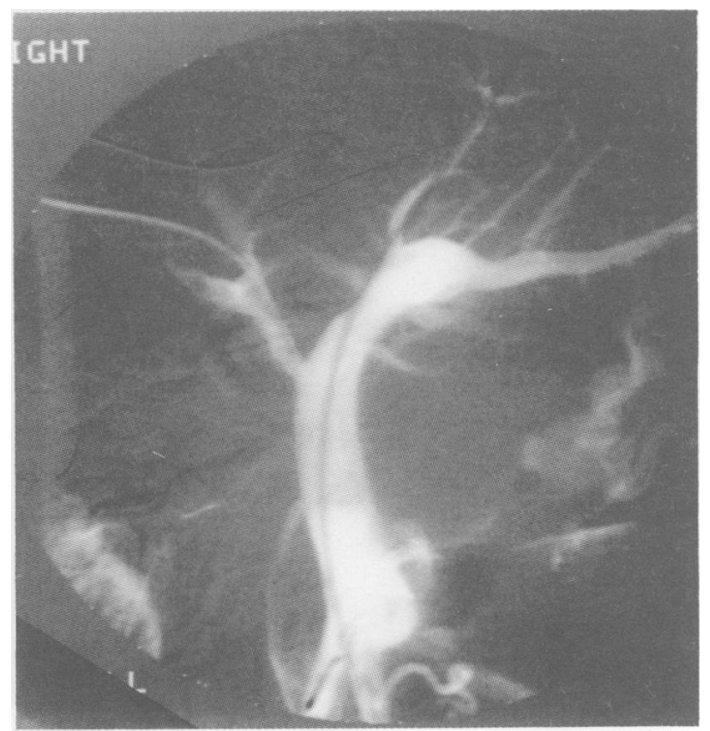

Figure 2: Portagram confirming position of catheter inserted into the portal vein after successful transjugular cannulation. 


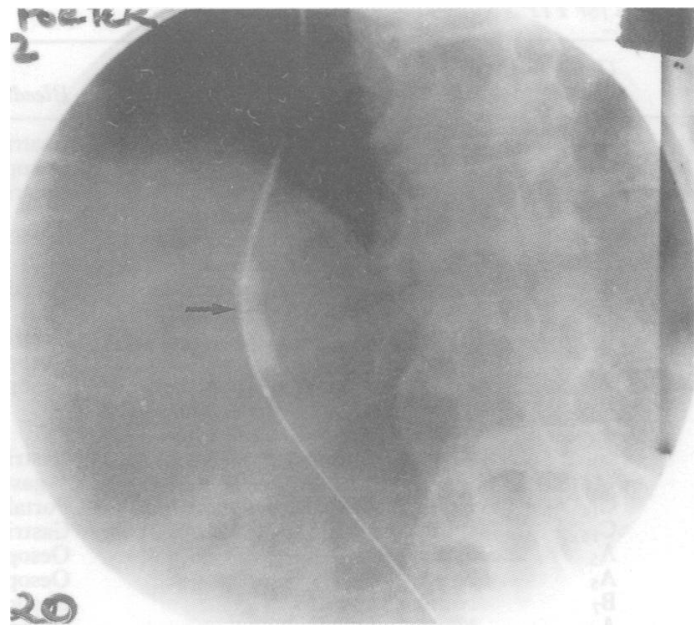

Figure 3: Inflation of the angioplasty balloon within the hepatic parenchyma may show a sharp waist (arrowed) related to the dense periportal fibrosis.

waist related to the dense periportal fibrosis was seen (Fig 3). After adequate dilatation of the tract, patency was maintained by the insertion of one or more Palmaz stents (Johnson and Johnson Interventional Systems, Edinburgh, UK) to cover the tract from portal to hepatic vein (Fig 4). After dilatation of the stents to $8 \mathrm{~mm}$, repeat measurements of portal pressure were made and the stents progressively dilated until the portal pressure gradient (direct portal pressure minus free hepatic venous pressure) fell below $15 \mathrm{~mm}$ Hg. The procedure took between two and six hours, less in the later cases. The most time consuming part was related to transjugplar cannulation of the portal vein.

After the procedure the patients were monitored for evidence of bleeding and prophylactic antibiotic (cefotaxime) was administered for 48 hours.

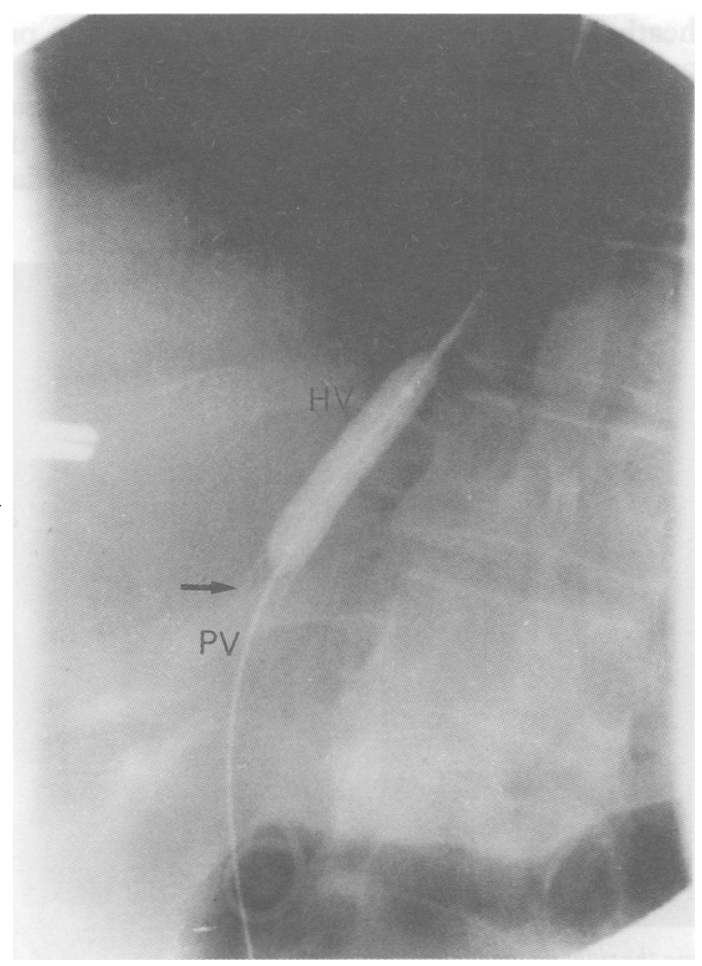

Figure 4: Placement of Palmaz stent proximal to stent inserted earlier (arrowed) to cover the tract from portal $(P V)$ to hepatic vein $(H V)$

\section{Results}

Table II shows the procedures undertaken and results of attempted TIPSS. In four patients the TIPSS was attempted as an emergency procedure and was successful in three cases. A successful TIPSS procedure was performed electively in 15 of 18 patients. For anatomical reasons it proved impossible to cannulate the portal vein in four patients, two were referred for surgical intervention, and one patient has required further admission for transfusion because of bleeding from portal gastropathy. One death related to the procedure occurred in patient 9 who had a small shrunken liver, gross ascites, and a coagulopathy not completely reversed by vitamin $\mathrm{K}$ and fresh frozen plasma. Six hours after the attempted TIPSS the patient developed fatal intraperitoneal haemorrhage from the liver parenchyma.

A number of complications prompted modification of our original technique. In patient 2 the tip of a fine 0.018 inch gauge guidewire was amputated in the liver parenchyma. Although this resulted in no clinical sequelae and did not migrate, we have subsequently abandoned the use of fine guidewires. In the same patient haemoperitoneum and haemothorax occurred and in a further patient a large subcutaneous haematoma was seen. These were treated conservatively and no transfusions were required. These complications were related to the percutaneous transhepatic insertion of a catheter into the portal vein to act as a target for the transjugular biopsy needle. Use of the portagram alone for guidance eliminated these complications. Before routine use of prophylactic antibiotics we noted two infective complications, namely Staphylococcal septicaemia and cellulitis at the jugular vein puncture site; both responded promptly to appropriate antibiotic treatment. Haemobilia after puncture of the biliary tree was seen in patient 6 and settled with conservative management. In the same patient mild clinical encephalopathy developed three days after TIPSS. This resolved with protein restriction and oral lactulose but recurred one month later and required readmission to hospital. The shunt size was reduced by placing an $8 \mathrm{~mm}$ stent within the $10 \mathrm{~mm}$ stent with clinical improvement (Fig 5) allowing the patient to be discharged. One month after TIPSS, patient 8 presented with mild clinical encephalopathy, this did not require hospital admission and was controlled by protein restriction and lactulose.

In 12 patients no further bleeding has been found during follow up (range 1-15 months). In patients with ascites there was resolution with a reduction in weight and a reduced requirement for diuretics. No deterioration in hepatic synthetic function occurred following successful TIPSS (Table III).

Patient 1 was admitted with reaccumulated ascites suggested poor shunt function. Although transabdominal ultrasound showed flow through the shunt, the patient died from massive variceal haemorrhage before further assessment could be undertaken. Postmorten examination showed the shunt to be patent. Patient 2 was readmitted two months after TIPSS with a further bleed 
TABLE II Results of TIPSS

\begin{tabular}{|c|c|c|c|}
\hline $\begin{array}{l}\text { Patient } \\
\text { No }\end{array}$ & Procedure & $\begin{array}{l}P P G^{\star} \text { post } \\
\text { TIPSS }(m m \mathrm{Hg})\end{array}$ & Procedure related complications \\
\hline 1 & $\begin{array}{l}\text { Middle hepatic vein - left portal vein, three } \\
\text { Palmaz stents }\end{array}$ & 10 & Subcutaneous haematoma \\
\hline 2 & $\begin{array}{l}\text { Right hepatic vein - proximal left portal vein, two } \\
\text { Palmaz stents }\end{array}$ & $29 / 14 \dagger$ & $\begin{array}{l}\text { Guide wire amputation, haemoperitoneum, } \\
\text { haemothorax }\end{array}$ \\
\hline 3 & $\begin{array}{l}\text { Right hepatic vein - right portal vein, three } \\
\text { Palmaz stents }\end{array}$ & 13 & Staphylococcal septicaemia \\
\hline 4 & Failed & - & None \\
\hline 5 & $\begin{array}{l}\text { Right hepatic vein - right portal vein, two Palmaz } \\
\text { stents }\end{array}$ & 8 & None \\
\hline 6 & $\begin{array}{l}\text { Right hepatic vein - right portal vein, two Palmaz } \\
\text { stents }\end{array}$ & 10 & Haemobilia \\
\hline 7 & $\begin{array}{l}\text { Right hepatic vein - right portal vein, two Palmaz } \\
\text { stents }\end{array}$ & 13 & None \\
\hline 8 & $\begin{array}{l}\text { Right hepatic vein - junction of right portal vein } \\
\text { with patent umbilical vein, two Palmaz stents }\end{array}$ & 15 & None \\
\hline 9 & Failed & - & Intraperitoneal haemorrhage and death \\
\hline 10 & $\begin{array}{l}\text { Right hepatic vein - right portal vein, three } \\
\text { Palmaz stents }\end{array}$ & 13 & None \\
\hline 11 & $\begin{array}{l}\text { Right hepatic vein - right portal vein, two Palmaz } \\
\text { stents }\end{array}$ & 15 & None \\
\hline 12 & Failed & - & None \\
\hline 13 & $\begin{array}{l}\text { Right hepatic vein - right portal vein, three } \\
\text { Palmaz stents }\end{array}$ & 12 & None \\
\hline 14 & $\begin{array}{l}\text { Right hepatic vein - right portal vein, two Palmaz } \\
\text { stents }\end{array}$ & 13 & None \\
\hline 15 & $\begin{array}{l}\text { Right hepatic vein - right portal vein, three } \\
\text { Palmaz stents }\end{array}$ & 12 & None \\
\hline 16 & $\begin{array}{l}\text { Right hepatic vein - right portal vein, three } \\
\text { Palmaz stents }\end{array}$ & 12 & None \\
\hline 17 & $\begin{array}{l}\text { Right hepatic vein - right portal vein, three } \\
\text { Palmaz stents, embolisation of left gastric vein }\end{array}$ & 10 & None \\
\hline 18 & Failed & - & None \\
\hline 19 & $\begin{array}{l}\text { Right hepatic vein - right portal vein, three } \\
\text { Palmaz stents, embolisation of left gastric vein }\end{array}$ & 14 & None \\
\hline 20 & $\begin{array}{l}\text { Right hepatic vein - right portal vein, three } \\
\text { Palmaz stents, embolisation of left gastric vein }\end{array}$ & 12 & None \\
\hline 21 & $\begin{array}{l}\text { Right hepatic vein - right portal vein, three } \\
\text { Palmaz stents, embolisation of left gastric vein }\end{array}$ & 10 & None \\
\hline 22 & $\begin{array}{l}\text { Right hepatic vein - right portal vein, four } \\
\text { Palmaz stents }\end{array}$ & 14 & None \\
\hline
\end{tabular}

$\star P P G=$ Portal pressure gradient (direct portal pressure - free hepatic venous pressure).

+PPG before insertion of an additional stent to open a thrombosed fistulous tract.

from oesophageal varices. Portography showed that the two stents inserted did not completely cover the parenchymal tract between the portal and hepatic veins and occlusion had occurred. A third stent was deployed more proximally and the stents further dilated from 8 to $10 \mathrm{~mm}$ resulting in a satisfactory pressure gradient of 14 $\mathrm{mm} \mathrm{Hg}$. During the past 10 months of follow up this patient, who had bled on 11 occasions over the previous six months, has not required further admission with recurrent haemorrhage. Single episodes of haemorrhage have been noted in four other patients related to shunt thrombosis (two), intimal hyperplasia within the shunt (one), and shunt migration (one). In the patient with intimal hyperplasia, angioplasty dilitation of the shunt reduced portal pressure and there was no further bleeding. In the patient with migration of the TIPSS deployment of a further stent has resulted in no further bleeding. One patient with shunt thrombosis has had a CVA and no attempt has been made to recannulise the shunt. The other patient has had successful recannulisation of his shunt and no further bleeding.

Follow up assessment of shunt patency has been undertaken using transabdominal ultrasound. In those in whom this failed to identify flow within the stent, transoesophageal duplex ultrasound was performed and has been particularly useful in obese patients. One patient had reaccumulated ascites but ultrasound showed good shunt flow. Portography was undertaken that showed hepatic vein stenosis. This was successfully treated by the insertion of a Palmaz stent within the hepatic vein.

\section{Discussion}

This paper details our experience with the TIPSS procedure. We have successfully carried out this procedure in 18 patients. In four patients cannulation of the portal vein was impossible for anatomical reasons. The indications for insertion of TIPSS in our series were recurrent bleeding from oesophageal varices despite injection sclerotherapy, bleeding gastric varices, and portal gastropathy. Bleeding from gastric varices responds poorly to injection sclerotherapy and often requires surgical intervention. ${ }^{34}$ Similarly, bleeding from oesophageal varices that have not responded to repeated sessions of injection sclerotherapy is a further indication for surgical intervention. ${ }^{5}$ Despite the short duration of follow up, we have been impressed with the effectiveness of TIPSS in controlling recurrent haemorrhage from oesophageal or gastric varices and portal hypertensive gastropathy.

We have experienced one death related to the procedure in a patient with coagulopathy, massive ascites, and a shrunken right lobe of liver. Complications have also occurred that caused us to modify our original technique; namely to abandon ultrafine guidewires, to use a reverse bevelled transjugular biopsy needle, and to avoid the percutaneous transhepatic placement of portal catheters for guidance. Two of our patients developed infective complications and we now use prophylactic antibiotics during and for 48 hours after the procedure.

In previously reported series encephalopathy after successful TIPSS is rare. ${ }^{26-30}$ This may be related to the maintenance of hepatopetal portal 


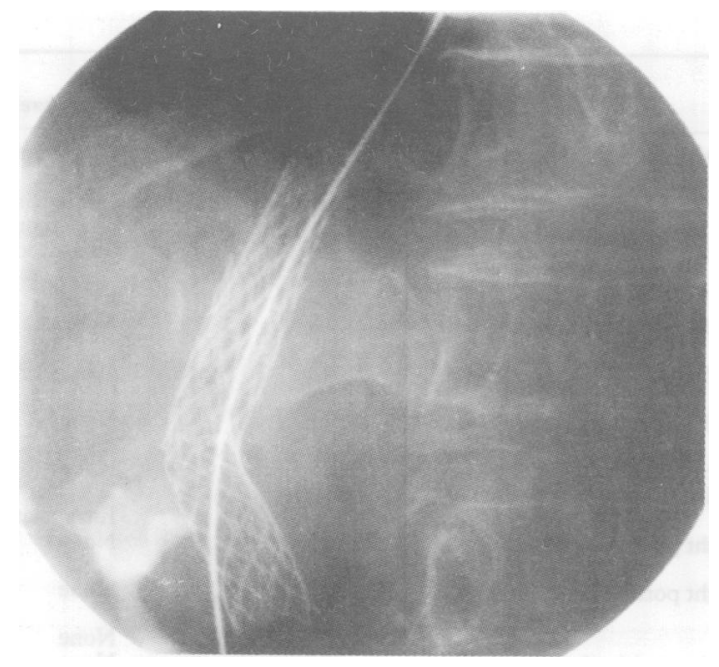

Figure 5: An $8 \mathrm{~mm}$ stent placed within a $10 \mathrm{~mm}$ stent to control encephalopathy after TIPSS.

blood flow as well as the small diameter of the shunt. We have noticed this complication in two elderly patients. Reduction of the diameter of the shunt by inserting an $8 \mathrm{~mm}$ stent within the original $10 \mathrm{~mm}$ stent resulted in improvement in encephalopathy in the more severe case. Clearly this important complication requires careful study with electrocephalography and psychometric testing before and after the procedure and longer term follow up.

The use of TIPSS would seem to be a valid alternative to surgery and has several advantages over either oesophageal transection or surgical shunts. Firstly, TIPSS avoids a general anaesthetic, laparotomy, and disruption of the hepatic portal venous system that may adversely affect subsequent hepatic transplantation..$^{35}$ TIPSS have been performed on patients without interfering with successful transplantation. ${ }^{32}$ Secondly, dilatation of the stents allows a graduated and controlled reduction in portal pressure. Aiming for a portal pressure gradient of 12-15 mm Hg might allow control of haemorrhage without inducing a high incidence of encephalopathy. Should this particular complication occur after creation of a successful shunt, it can be improved as described for patient 6 .
As experience with TIPSS increases, so the indications for this procedure may expand. Improvement of ascites was found after TIPSS associated with a diuresis and it may, therefore, be useful in patients with intractable ascites. TIPSS could be undertaken in the acute situation or soon after haemostatic injection sclerotherapy for the index bleed in patients with a high risk of rebleeding but this requires evaluation in controlled trials. TIPSS may also become the treatment of choice for bleeding from portal hypertensive gastropathy in patients intolerant of propranolol ${ }^{36}$ and in the uncommon cases of patients bleeding from varices at ectopic sites. Other workers have undertaken TIPSS before closure of a surgical portasystemic shunt in a patient with chronic encephalopathy. ${ }^{30}$

In summary, we have successfully carried out TIPSS in 18 patients with control of bleeding from gastric or oesophageal varices and portal hypertensive gastropathy. Ascites improved when it was present. The complications found have prompted alterations in technique to minimise the procedure related morbidity. We believe TIPSS to be a valuable treatment in the management of selected patients with gastrointestinal bleeding associated with portal hypertension but fuller evaluation of its indications, safety, and efficacy is required before it is adopted into general clinical practice.

We acknowledge the help of Dr George Sutherland who performed the transoesophageal duplex ultrasounds, Mrs Jean Johnstone for secretarial help and the Urquhart Trust and Sir Stanley and Lady Davidson Trust for financial support.

1 Gimson AES, Westaby D, Hegarty J, Watson A, Williams R. a randomised trial of vasopressin and vasopresin plus nitroglycerin in the control of active variceal haemorrhage. Hepatology 1986; 6: 410-13.

2 Burroughs AK, McCormick PA, Hughes MD, Sprengers D D'Heygele F, McIntyre R. Randomised double-blind placebo-controlled trial of somatostatin for variceal bleeding. Emergency control and prevention of early variceal reing. Emergency control and prevention of ea

3 Panés J, Terés J, Bosch J. Efficacy of balloon tamponade in treatment of bleeding gastric and oesophageal varices. Results in 151 consecutive episodes. Dig Dis Sci 1988; 33. 454-9.

4 Westaby D, Hayes PC, Gimson AES, Polson RJ, Williams R. Controlled trial of injection sclerotherapy for active variceal bleeding. Hepatology 1989; 9: 274-7.

5 Burroughs AK, Hamilton G, Philips A, Mezzanotte G, McIntyre N, Hobbs KEF. A comparison of sclerotherapy with staple transection of the oesophagus for the emergency control of bleeding from oesophageal varices. $N \mathrm{Engl} F \mathrm{Med}$ 1989; 321: 857-62.

TABLE III Liver function tests before and after TIPSS

\begin{tabular}{|c|c|c|c|c|c|c|c|c|}
\hline \multirow[b]{2}{*}{$\begin{array}{l}\text { Patient } \\
\text { No }\end{array}$} & \multirow[b]{2}{*}{$\begin{array}{l}\text { Prothrombin } \\
\text { ratio }\end{array}$} & \multirow{2}{*}{$\begin{array}{l}\text { Prep-TIPSS } \\
\text { bilirubin } \\
(\mu \mathrm{mol} / \mathrm{l})\end{array}$} & \multirow[b]{2}{*}{$\begin{array}{l}A L T \\
(U / l)\end{array}$} & \multirow[b]{2}{*}{$\begin{array}{l}\text { GGTP } \\
(U / l)\end{array}$} & \multicolumn{4}{|c|}{ Post-TIPSS (4 days) } \\
\hline & & & & & $\begin{array}{l}\text { Prothrombin } \\
\text { ratio }\end{array}$ & $\begin{array}{l}\text { Bilirubin } \\
(\mu \mathrm{mol} / l)\end{array}$ & $\begin{array}{l}A L T \\
(U / l)\end{array}$ & $\begin{array}{l}\text { GGTP } \\
(U / l)\end{array}$ \\
\hline 1 & $1 \cdot 2$ & 18 & 11 & 93 & $1 \cdot 5$ & 33 & 15 & 51 \\
\hline 2 & $1 \cdot 2$ & 31 & 27 & 194 & $1 \cdot 2$ & 21 & 24 & 116 \\
\hline 3 & $1 \cdot 0$ & 26 & 65 & 272 & 1.0 & 32 & 181 & 261 \\
\hline 4 & $1 \cdot 3$ & 55 & 10 & 35 & - & - & - & - \\
\hline 5 & $1 \cdot 1$ & 55 & 35 & 543 & $1 \cdot 1$ & 17 & 133 & 427 \\
\hline 6 & $1 \cdot 2$ & 17 & 41 & 54 & 1.0 & 57 & 202 & 84 \\
\hline 7 & 1.5 & 12 & 16 & 36 & 1.0 & 46 & 28 & 45 \\
\hline 8 & 1.4 & 102 & 33 & 140 & 1.4 & 136 & 44 & 158 \\
\hline 9 & 1.7 & 161 & 35 & 27 & - & - & - & - \\
\hline 10 & 3.8 & 111 & 49 & 8 & 2.25 & 158 & 27 & 34 \\
\hline 11 & $1 \cdot 2$ & 12 & 16 & 85 & $1 \cdot 0$ & 16 & 20 & 130 \\
\hline 12 & $1 \cdot 0$ & 16 & 133 & 89 & - & - & - & - \\
\hline 13 & $1 \cdot 3$ & 53 & 55 & 31 & - & 56 & 117 & 33 \\
\hline 14 & 1.0 & 62 & 72 & 365 & $1 \cdot 0$ & 103 & 194 & 373 \\
\hline 15 & 1.5 & 124 & 47 & 18 & 1.5 & 113 & 28 & 24 \\
\hline 16 & $1 \cdot 0$ & 25 & 38 & 404 & $1 \cdot 0$ & 21 & 82 & 424 \\
\hline 17 & 1.8 & 102 & 209 & 61 & 1.6 & 74 & 122 & 105 \\
\hline 18 & $1 \cdot 2$ & 24 & 14 & 33 & - & - & - & - \\
\hline 19 & 1.0 & 23 & 55 & 228 & 1.0 & 35 & 42 & 135 \\
\hline 20 & $1 \cdot 2$ & 36 & 18 & 131 & 1.0 & 59 & 35 & 477 \\
\hline 21 & $1 \cdot 3$ & 139 & 10 & 36 & $1 \cdot 2$ & 51 & 15 & 312 \\
\hline 22 & $1 \cdot 2$ & 6 & 11 & 161 & - & 126 & 411 & 284 \\
\hline
\end{tabular}


6 Anonymous. Emergency portacaval shunts. Lancet 1991; 337: 952.

7 Hayes PC, David JM, Lewis JA, Bouchier IAD. Meta-analysis of value of propranolol in prevention of variceal haemorrhage. Lancet 1990; 336: 153-6.

8 Hayes PC. Prevention of recurrent variceal bleeding. Pharmacological measures. Gastro Endosc Clin North Am 1992; 2: 137-50.

9 Terblanche J, Bornman PC, Delawir K, Jonker MAT, Campbell JẢH, Wright J, et al. Failure of repeated injection campbell JAH, Wright J, et al. Failure of repeated injection sclerotherapy to improve long-term survival after
geal variceal bleeding. Lancet 1983 ; ii: $1328-32$.

10 Westaby D, MacDougall BRD, Williams R. Improved survival following injection sclerotherapy for oesophageal varices. Final analysis of controlled trial. Hepatology 1985; 5: 627-31.

11 Westaby D. Prevention of recurrent variceal bleeding: endoscopic techniques. Gastro Endosc Clin North Am 1992; 2: 121-50.

12 Garden OJ, Mills PR, Birnie GG, Murray GD, Carter DC. Propranolol in the prevention of recurrent variceal haemorrhage in cirrhotic patients: a controlled trial. Gastroenterology 1990; 98: 185-90.

13 Henderson JM, Kutner MH, Millikan WJ, Galambos JT, Riepe SP, Scott Brooks W, et al. Endoscopic variceal
sclerosis compared with distal splenorenal shunt to prevent sclerosis compared with distal splenorenal shunt to prevent
recurrent variceal bleeding in cirrhosis. Ann Int Med 1990; recurrent varic

14 Harley HAJ, Morgan T, Redeker AG, Reynolds TB, Villamil $F$, Weiner JM, et al. Results of a randomized trial of end-toside portacaval shunt and distal splenorenal shunt in alcoholic liver disease and variceal bleeding. Gastroenterology 1986; 91: 802-9.

15 Langer B, Taylor BR, MacKenzie DR, Gilas T, Stone RM, Blendis L. Further report of a prospective randomized trial comparing distal splenorenal shunt with end-to-side portacaval shunt. Gastroenterology 1985; 88: 424-9.

16 Jackson FC, Perrin EB, Felix WR, Smith AG. A clinical investigation of the portacaval shunt: survival analysis of the investigation of the portacaval shunt: survival analysis

17 Dean Warren W, Galambos JT, Riepe SP, Henderson JM, Brooks WS, Salam AA, et al. Distal splenorenal shunt versus endoscopic sclerotherapy for long-term management of variceal bleeding. Ann Surg 1986; 203: 454-62.

18 Rösch J, Hanafee WN, Snow H. Transjugular portal venography and radiologic portacaval shunt: an experimental study, Radiology 1969; 92: 1112-4.

19 Rösch J, Hanafee WN, Snow H, Barenfus M, Gray R. Transjugular intraphepatic portacaval shunt: an experimental work. Am ₹ Surg 1971; 121: 588-92.

20 Palmaz JC, Sibbit RR, Reuter SR, Garcia F, Tio FO. Expandable intrahepatic portacaval shunt stents: early experience in the dog. Am $\mathcal{F}$ Roentgenol 1985; 145: 821-5.

21 Palmaz JC, Garcia F, Sibbitt RR, Tio FO, Kopp DT Schwesinger W, et al. Expandable intrahepatic portacava shunt stents in dogs with chronic portal hypertension. $A m \mathcal{f}$ Roentgenol 1986; 147: 1251-4.
22 Rösch J, Uchida BT, Putnam JS, Buschman RW, Law RD, Hershey, AL. Experimental intrahepatic portacaval anastomosis: use of expandable Gianturco stents. Radiology 1987; 162: 481-5.

23 Colapinto RF, Stronell RD, Birth SJ, Langer B, Blendis LM, Greig PD, et al. Creation of an intrahepatic portosystemic shunt with a Grüntzig balloon catheter. Can Med Assoc $\mathcal{7}$ 1982; 126: 267-8.

24 Colapinto RF, Stronell RD, Gildiner M, Ritchie AC, Langer B, Taylor BR, et al. Formation of intrahepatic portosystemic shunts using a balloon dilatation catheter: preliminary clinical experience. Am $\mathcal{f}$ Roentgenol 1983; 140: 70914.

25 Richter GM, Palmaz JC, Nöldge G, Rössle M, Siegerstetter V, Franke $M$, et al. Der transjuguläre intrahepatische portosystemische stent-shunt (TIPSS). Radiologe 1989; 29: 40611 .

26 Rössle M, Richter GM, Nöldge G, Palmaz JC, Wenz W, Gerok $W$. New non-operative treatment for variceal haemorrhage [letter]. Lancet 1989; i: 153.

27 Richter GM, Noeldge G, Palmaz JC, Roessle M, Siegerstetter $\mathrm{V}$, Franke $M$, et al. Transjugular intrahepatic portacaval stent shunt: preliminary clinical results. Radiology 1990; 174: $1027-30$.

28 Zemel G, Katzen BT, Becker GJ, Benenati JF, Skip Sallee D. Percutaneous transjugular portosystemic shunt. $\mathcal{F} A M A$ 1991; 266: 390-3.

29 Rossle M, Noldge G, Pararnau JM, Haag K, Sellinger M, Wenz W, et al. Transjugular intrahepatic portosystemic stent-shunt (TIPSS): experience with an improved technique. Hepatology 1991; 14: 96A.

30 Vinel JP, Rousseau H, Maquin P, de Haldat F, Blain F, Joffre $\mathrm{F}$, et al. Transjugular intra-hepatic porto-caval shunts (ICPS): experimental and clinical study. Hepatology 1991; 14: 234A.

31 La Berge JM, Ring EJ, Gordon RL. Percutaneous intrahepatic portosystemic shunt created via a femoral vein approach. portosystemic shunt created
Radiology $1991 ; 181: 679-81$.

32 Ring EJ, Lake JR, Roberts JP, Gordon RL, LaBerge JM, Read AE, et al. Using transjugular intrahepatic portosystemic shunts to control variceal bleeding before live transplantation. American College of Physicians 1992; 116 304-9.

33 Chalmers N, Redhead DN, Simpson KJ, Hayes PC. Transjugular intrahepatic portosystemic stent shunt (TIPSS): Early clinical experience. Clin Radiol 1992; 46: 166-9.

34 Soehendra N, Grimm H, Nam V, Berger B. N-butyl-2cyanoacrylate, a supplement to endoscopic sclerotherapy. Endoscopy 1987; 19: 221-4.

35 Brems JJ, Hiatt JR, Kleen AS, Millis JM, Colonna JO Quinones-Baldrich WJ, et al. Effect of prior portasystemic shunt on subsequent liver transplantation. Ann Surg 1989; 209: $51-6$.

36 Pérez-Ayuso RM, Piqué JM, Bosch J, Panés, Gonzalez A Péres $R$, et al. Propranolol in prevention of recurren bleeding from severe portal hypertensive gastropathy in cirrhosis. Lancet 1991; 337: 1431-4. 